\title{
Histo-Pathological Study in Chickpea (Cicer arietinum. L) Plant Parts Infected with Fusarium oxysporum f.sp ciceri
}

\author{
P. J. Rathod*, D. N. Vakharia and A. G. Vala \\ Department of Biochemistry and Biotechnology, College of Agriculture, Junagadh \\ Agricultural University, Junagadh-362001 (Gujarat) India \\ *Corresponding author
}

\section{A B S T R A C T}

Keywords

Chickpea, Wilt, Histopathology

Article Info

Accepted:

18 May 2020

Available Online:

10 June 2020
A study was carried out periodically using PDA (Potato Dextrose agar) media to see the presence and absence of spore and mycelium growth in chickpea root, stem and leaf tissue infected with Fusarium oxysporum f.sp ciceri . The tissues were obtained from infected plots at different stages of plant growth. Results showed that fungal mycelium was isolated on PDA medium, starting from the first day, medium starting from the first day after germination media from 1 to 19 DAG (Days after Germination). Root and stem tissues collected from sick plot was shown fungal growth on media at 8 to 10 DAG in all the cultivars. Highly susceptible cultivars JG -62 and GG-4 were exhibited rapid fungal growth, vascular browning, and the occlusion of xylem vessels of root tissues with fungal hyphae than the other susceptible cultivars. Study also revealed that only PDA media growth was not enough to decide the particular stages of infection but microtome or histological observation indicated the clear cut ideas for deciding stages of infections.

\section{Introduction}

Chickpea (Cicer arietinum. L) is the second most important pulse crop of the world. A number of pathogens affecting chickpea had shown a three fold increase during last 15 years (Nene et al., 1996). The main fungi that affect chickpea are Fusarium oxysporum Schlechtend.:Fr. f.sp. ciceri (Padwick) Matuo
\& K. Sato, causing the plant wilt. Annual yield losses due to Fusarium oxysporum. f.sp. ciceri have been estimated to range from 10 to $15 \%$ but Fusarium wilt epidemics can be devastating to individual crops and cause $100 \%$ loss under favorable conditions (Halila and Strange, 1996; Chaube and Pundhir, 2005). There must be knowledge of the geographical distribution of $F$. oxysporum $f$. 
sp. ciceris-races is requires for disease management, because individual races vary in their interaction with differential chickpea lines as well as in the amount of inoculum needed to induce a given amount of disease in susceptible chickpeas(Jimenez-Fernandez et al. 2013). Fusarium oxysporum has been reported in other crops at different stages of the infection process, preventing or retarding penetration or colonisation in epidermis, cortex or endodermis of the roots as mechanisms of extravascular resistance, or later in the xylem of roots and/or stem as mechanisms of vascular resistance (Baayen et al. 1991; Jimenez-Fernandez et al. 2013, Pouralibaba, 2017). It is essential to see histological intervention in the infection process, as well as to determines the resistance mechanism in plants, cultivars indifferent environments and field condition. Therefore, this study was initiated to find out histopathological changes in stem and roots of six cultivars differed in resistance to wilt infection. PDA media study was designed to judge or finalizing the disease initiations and infectional and post infectional stages with the supporting of microtome as well as through transverse section of root and stem tissues at each stage.

\section{Materials and Methods}

Six cultivars of chickpea viz WR-315, JCP27, GG-1, GG-2, GG-4 and JG-62 grown in normal plot i.e. in natural soil which is assumed as healthy soil as well as grown in infested soil plot ( artificially inoculated with Fusarium oxysporum f.sp. ciceris race-2). since 1998 and designated as sick plot for this fungus. These plots are located at Pulse research Farm, Junagadh Agricultural University Junagadh. Roots from healthy and diseased plants were collected from the field at different stages by visible wilt symptoms of cultivars grown in inoculated plot (infested plot). (i) Pre-infectional (Normal, Leaves were healthy and green in all cultivars: 12 Days after sowing-S $\mathrm{S}_{1}$ ), (ii) Disease inflectional stage (Leaves drooping in most of cultivars, except slightly drooping in WR-315 and JCP-27) and (iii) Post inflectional stage (Leaves pale yellow and wilted, drooping of whole plants but not all cultivars (JG-62).-26DAS) whole plants packed in plastic bags and brought to the laboratory under the ice cold conditions. Plants parts were separated, cleaned, weighed and then transferred immediately to the respective medium for various analyses. Samples were stored in deep freezer $\left(-70^{\circ} \mathrm{C}\right)$ until analysis was over.

\section{Preparation of PDA medium}

Preparation of Potato dextrose agar Media: $200 \mathrm{~g}$ potato tuber (pieces) peeled off was partially boiled in distilled water, boiled water having soluble potato starch was filtered and volume was made up to $1000 \mathrm{ml}$. To this 20 $\mathrm{g}$ agar was added and the content was sterilized in autoclaved at 120 pound pressure for 15 minutes. Autoclaved 20ml of PDA liquid culture was than poured in petri plate (9cm diameter) and allowed to solidify at room temperature.

\section{Presence or absence of fungal mycelium/spores on PDA media}

Chickpea plants were grown in infested soil with Fusarium oxysporium f.sp. ciceris and used to see the progress of fungal mycelium/spores in the tissues of cultivars, For that procedure described by the Stevenson et al., (1997) and Pandey et al., (1995) were followed days after germination of chickpea. Uprooted seedlings were washed thoroughly under tap water and made free from soil particles. (Root up to $2 \mathrm{~cm}$ below of hypocotyls), stem up to $2 \mathrm{~cm}$ above hypocotyls, and upper leaf tissue were separated from the up rooted seedlings of all six cultivars and sterilized with $70 \%$ alcohol 
for about $1 \mathrm{~min}$ and $20 \% \mathrm{v} / \mathrm{v}$ solution of $0.02 \%$ sodium hypochlorite for 3 minutes. The sterilized tissues were washed with sterilized water and transferred on PDA media in Petri plates and kept $25^{\circ} \mathrm{C}$ in B.O.D incubator. After three days the presence of fungal mid / spores were noted in different plates till the 19 Days after Germination.

\section{Histopathological study}

Histological study was carried out to observe the fungal spore/mycelium growth of Fusarium oxysporium f. sp. ciceris in plant tissues, Transverse section of fresh root and stem tissues of all six cultivars were taken and stained with lactophenol blue to observe fungal growth under microscope. Microtome sections were prepared according to the method described by Sass (1964).One cm size tissues were separated from the plant and first fixed in $35 \%$ formaldehyde: glacial acetic acid: distilled water in the ratio of 50:10:35. Fixed tissues were dehydrated with series of treatment of tertiary butyl alcohol and xylene and distilled water at 2 hours interval in ratio of $5: 1: 4,5: 2: 3,5: 3.5: 1.5,5: 4.5: 4.5 ; 2.5: 7.5: 0$ and $0: 1.0: 0$ than wash with tertiary Butyl alcohol and xylene 7.5:2.5:0, 5:5:0, 2.5:7.5:0, and 0:1:0 at 2hrs interval. After dehydration, tissues were given three washes of melted wax $58-60{ }^{\circ} \mathrm{C}$ at 24 hours interval.

Tissues thus infiltrated with wax were fixed in (1 cm square size) wax block. Manually prepared wax block was used for taking microtome sections (15 microne size transverse section). The sections were fixed on $1 \%$ gelatin layer $(1 \mathrm{~g}$ granular gelatine $/ 100 \mathrm{ml}$ water) before observing under microscope. All section were observed using light microscope attached with rolled camera. And photographic film were using for prints. After seeing colour prints, scan jpeg, digital format was formed.

\section{Results and Discussion}

\section{Medium study and visual observation}

A study was carried out periodically using PDA (Potato Dextrose agar) media to see the presence and absence of spore and mycelium plant parts in. Cultivars viz JCP-27, WR-315, GG-1 and GG-2 did not show any sign of disease, while cultivars JG-62 and GG-4 had initiation of the disease symptoms after 7DAG. (Fig. 2). Root tissues and stem tissues from infested plot showed growth of fungus in medium at 8 to $10 \mathrm{DAG}$ in all six cultivars revealed that fungi was able to penetrate in both the tissues but it could not attack survive in both resistant cultivars JCP-27 and WR315 and also the tolerant cultivars GG-1 and GG-2. The fungus was not able to produce any wilt symptoms and no browning in vertical sections of collar region was observed. In susceptible cultivars JG -62 and GG-4 rapid fungal growth, vascular browning and the occlusion of xylem vessels of root tissues were observed.

As seen in plate in (figure 1) infested plot grown seedling collapsed and started bending towards ground. Whole seedlings collapsed and fell flat on the ground. The seedlings at early infection stage retained almost green colour in all six varieties. Collapsed seedling when up rooted showed uneven shrinking above and below the collar region. The shrunk portion was one inch longer. Affected seedling did not show rotting on outer surface. However, when split open vertically from collar region down-ward and up-ward about $1 \mathrm{~cm}$, browning colour portion of internal tissue was clearly visible in disease infected tissue grown in sick plots at infectional stage $\left(\mathrm{S}_{2}\right)$.

Visuals observation indicated that the seedlings of JG-62 that died earlier than all the cultivars, some severely infected tissue 
died after 72-96 hours and root tip browning observed (fig. 3). During progress of disease, drooping of petioles and rachis occurred along with leaf lets drooping was visible and initially at the upper part of plant but within a day or two, it was severe in entire plant of JG62. The lower leaves were chloritic, but most of other leaves wilted while retaining full green colour. Gradually however all the leaves turn yellow and than light brown or straw colour. Dried leaf lets of infected plants were not shaded at maturity. Affected fresh plants showed no external rotting, drying or discoloration of roots, when half the branches of split collar region of the affected plants were held in each hand pulled downward internal discoloration was observed (fig.3) Around the collar region, above and below the central inner portion (pith) showed dark brown colour of the xylem, which were continuously discoloration continued several $\mathrm{cm}$ above the collar region(up to 3 to 4 internodes) in the main stem. So the experiment checks line as JG-62 and comparing other resistant variety WR-315 and JCP-27. These seedlings show ever green during this period. Where as slight drooping was observed in GG-1, GG-2 and incase of GG-4 having more severe infection than the GG-1 and GG-2 but lesser than the JG-62.

There were presence of spores in outer layer of root tissues but infection was not observed during same period of in cultivar WR-315 and JCP-27. So pathogen with media study only did not clearly indicated that this stage was infectional but cross section of the all cultivars showed suitable stage for deciding infectional stage as shown in Table.1. Leaf tissues on PDA media growth and histological study did not show any growth of fungus observed during any infection or severely infection stage.
Observations on histological study of root and stem tissues during infectional stage in sick plots grown and normal plot grown have been presented in (fig 4,5 and 6). Observed differences were in xylem vessels of diseased stem and root tissues were full of hyphal presence due to fungal invasion whereas healthy plants did not showed any presence of hyphae or spore. Transverse section of root and stem tissue of diseased plant of all cultivars showed the presence of fungal hyphae in xylem vessels, dark brown cortex and almost xylem vessels were occluded. Whereas normal grown plant of all cultivars showed healthy appreance of xylem vessels and cortex region in transverse section of both root and stem tissue (fig 7-8).

Presence of fungal mycelium in root tissue of infested plot grown JG-62 and GG-4 cultivars revealed that fungi was able to penetrate the root tissue but it could not survive attack in WR-315 and GG-1, GG-2 as it was unable to produce any wilt disease symptoms up to 12 DAG as well as no browning of internal tissues.

The special emphasis and care were taken to decide the severity of infection and choosing plant to analysis under study. Observations recorded on fungal infected tissues of chickpea seedlings of all six cultivars have been presented in Table.1 (root tissue below $2 \mathrm{~cm}$ hypocotyls attachment). Results indicated that the cultivar JG-62 showed infection in stem and root tissues at 6 DAG than at and $7^{\text {th }}$ days after germination GG-4 in root tissues and subsequently presence of fungus observed in all remaining cultivars at starting from 9th days after germination in all six cultivars infected in some portion of stem and whole root surface of remaining cultivars as seen in Table. 1. 
Figure.1 External symptoms developed in chickpea plants obtained from sick plot and normal plot at different stages of diseased development or at crop growth stages

Sick plot

Pre infectional stage $\left(S_{1}\right)$

Normal plot
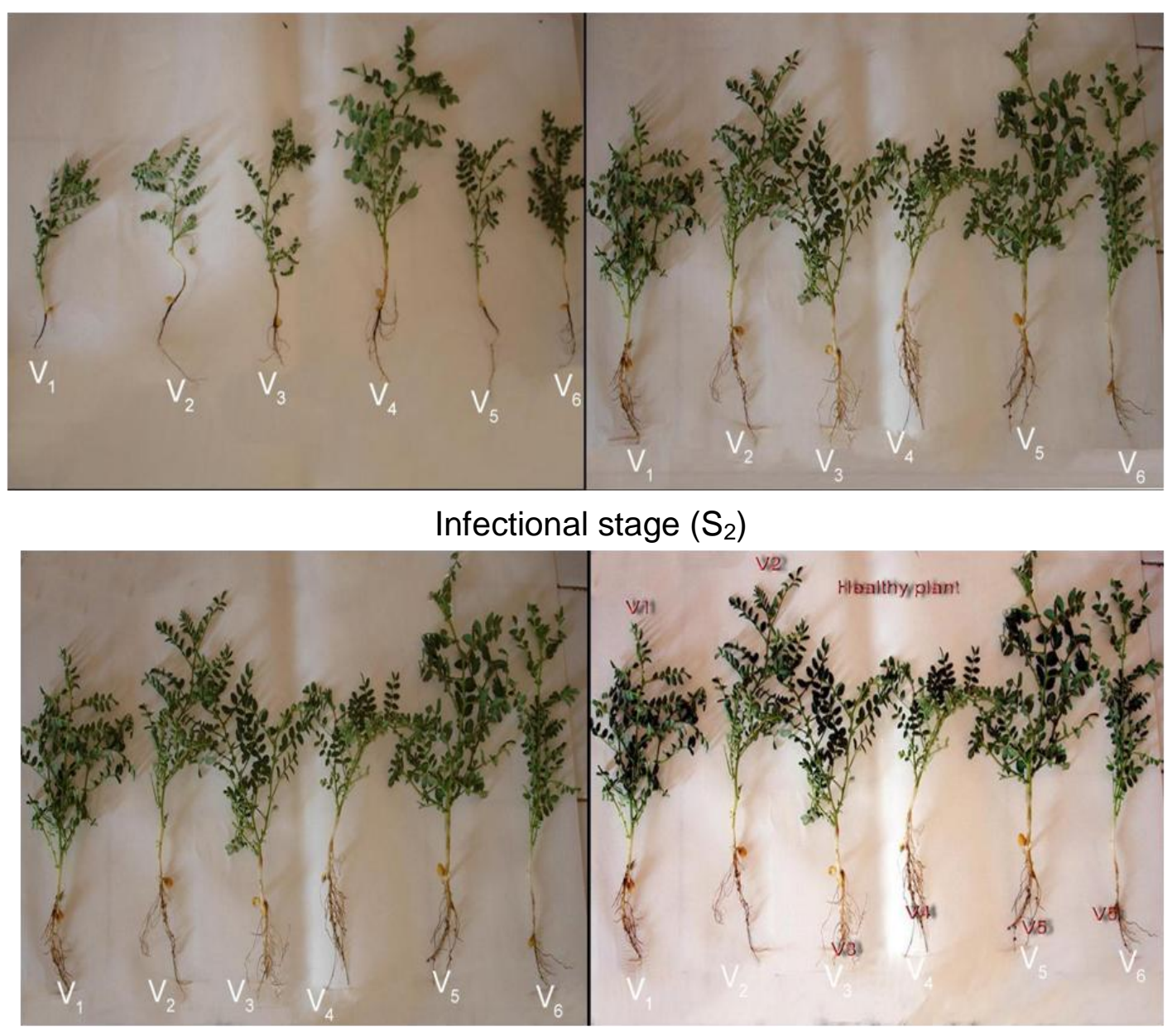

Post infectional stage $\left(\mathrm{S}_{3}\right)$

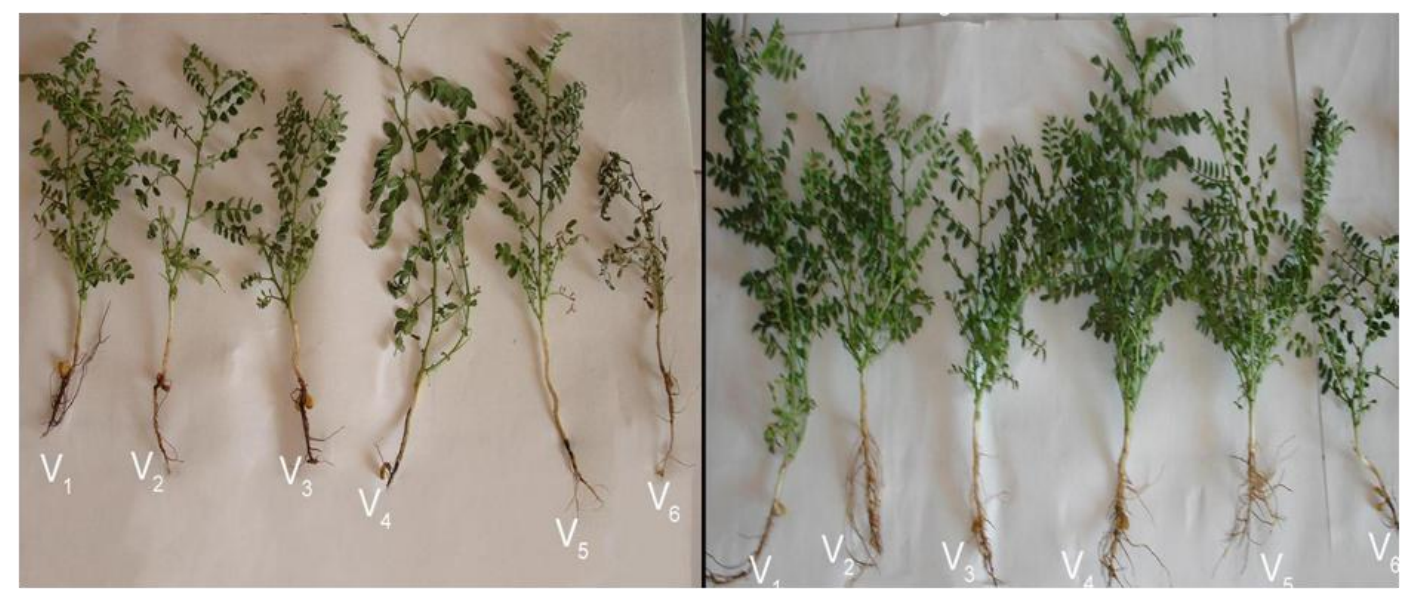


Figure.2 Presence or absence of fungal mycelium/spores in (leaf, stem and root) tissues of chickpea on PDA media at different intervals

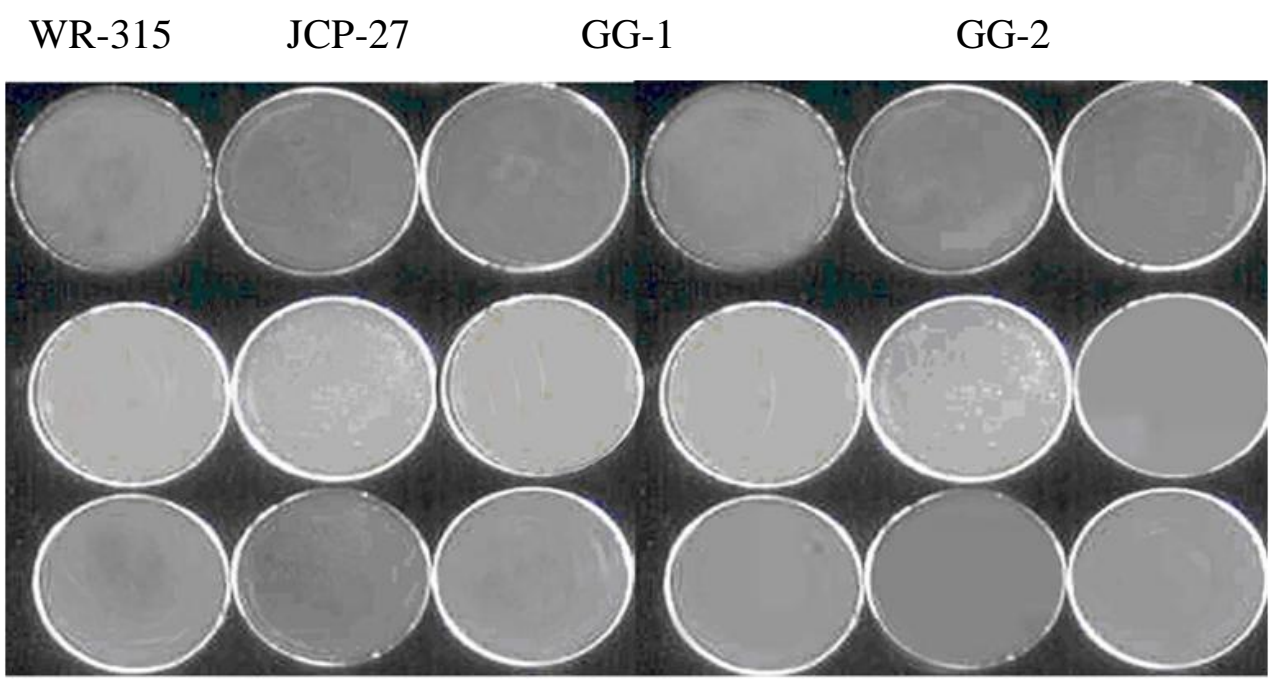

Leaf

Stem

Root

Pre infectional stage $\left(\mathrm{S}_{1}\right)$

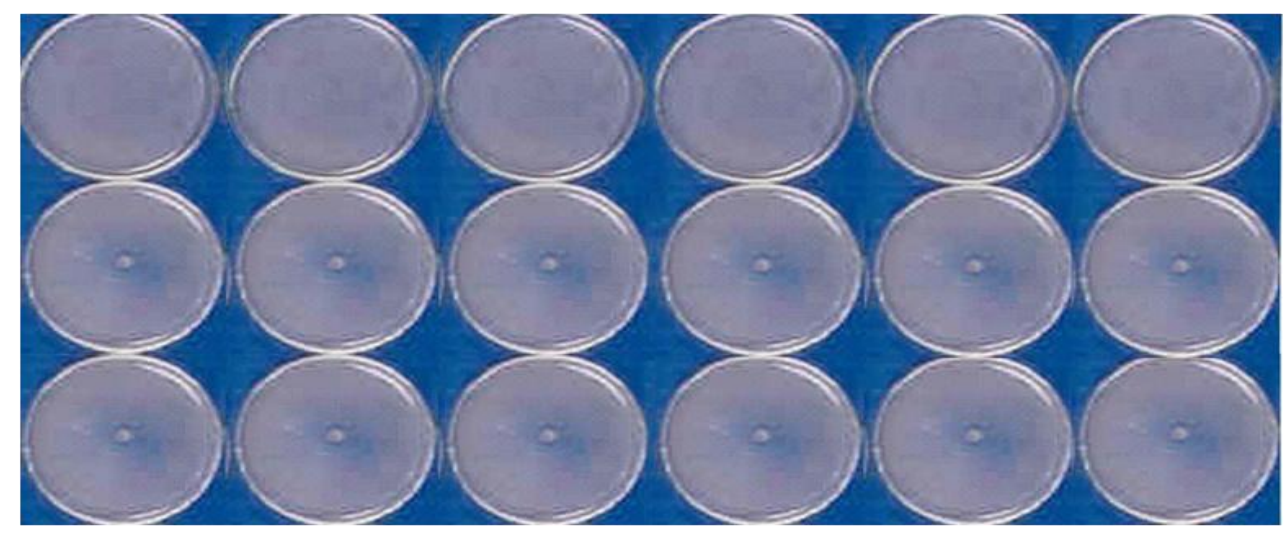

Leaf

Stem

Root

Infectional stage $\left(\mathrm{S}_{2}\right)$

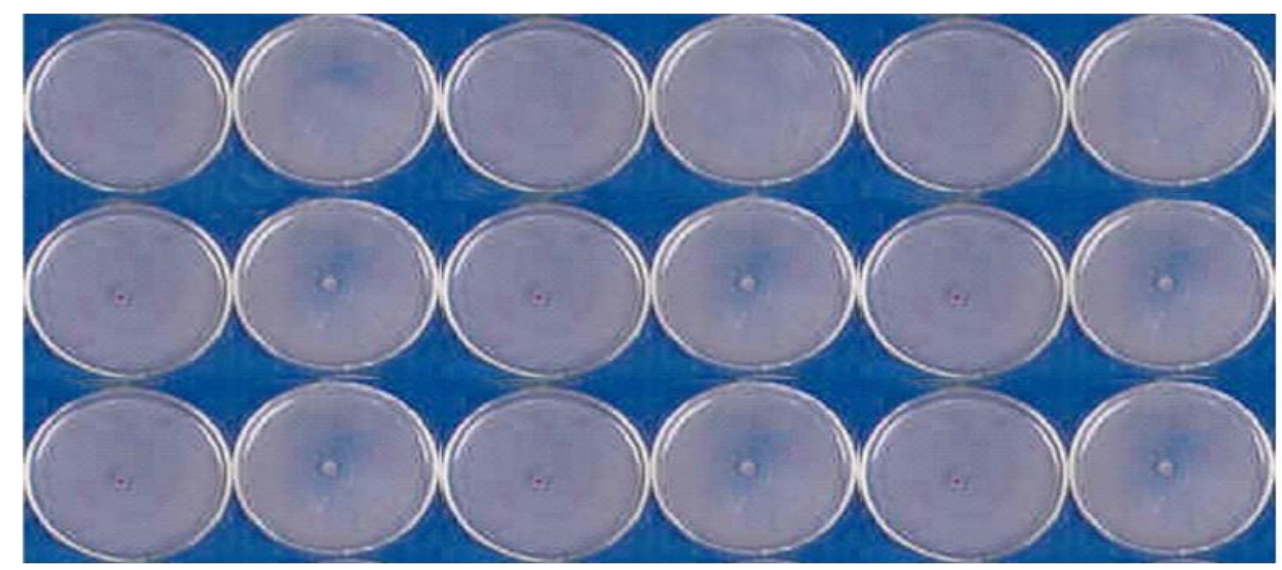

Leaf

Stem

Root

Post infectional stage $\left(\mathrm{S}_{3}\right)$ 
Figure.3 Observations on browning reaction in vertical section of collar region of healthy and diseased root

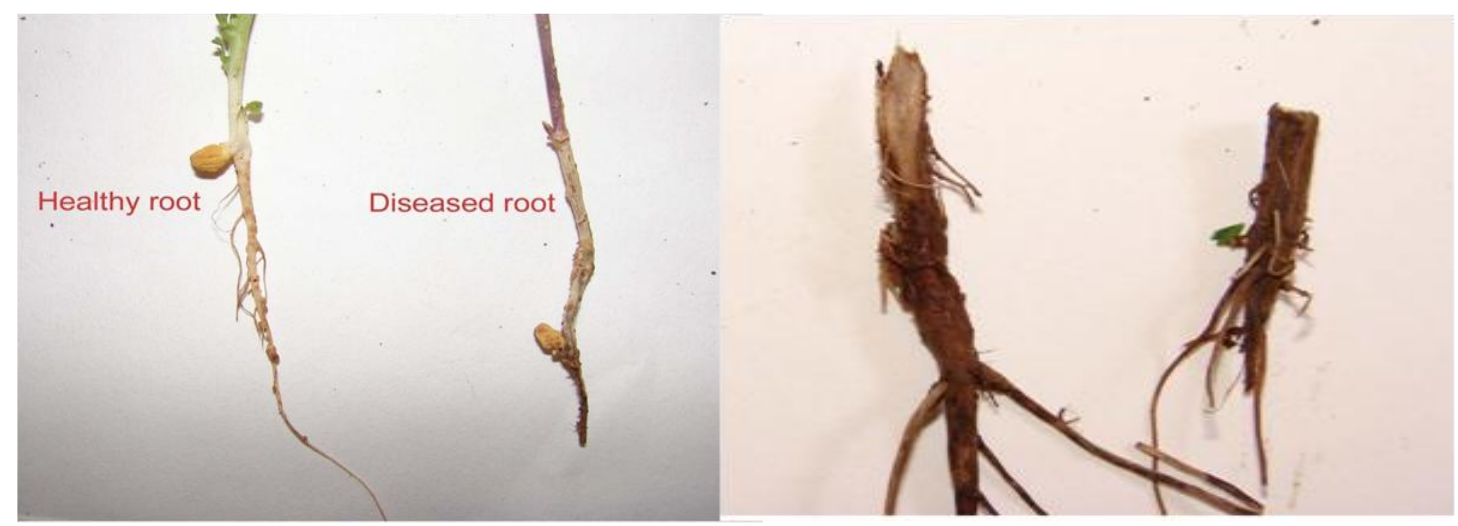

Figure.4 Histological study of root tissues through microtome section at different stages of infection in sick plot
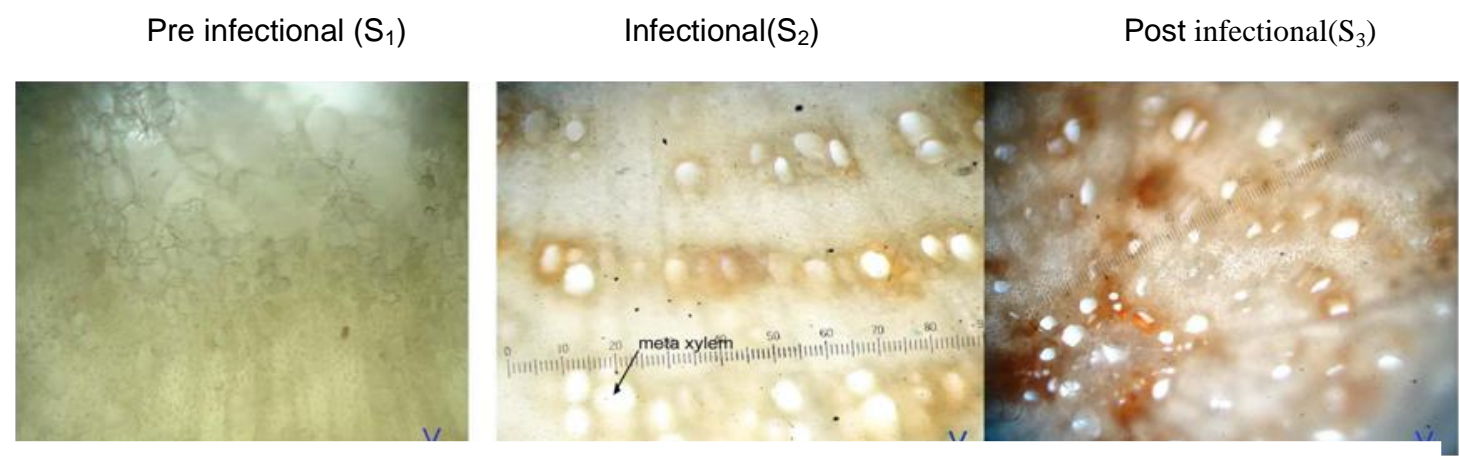

WR-315
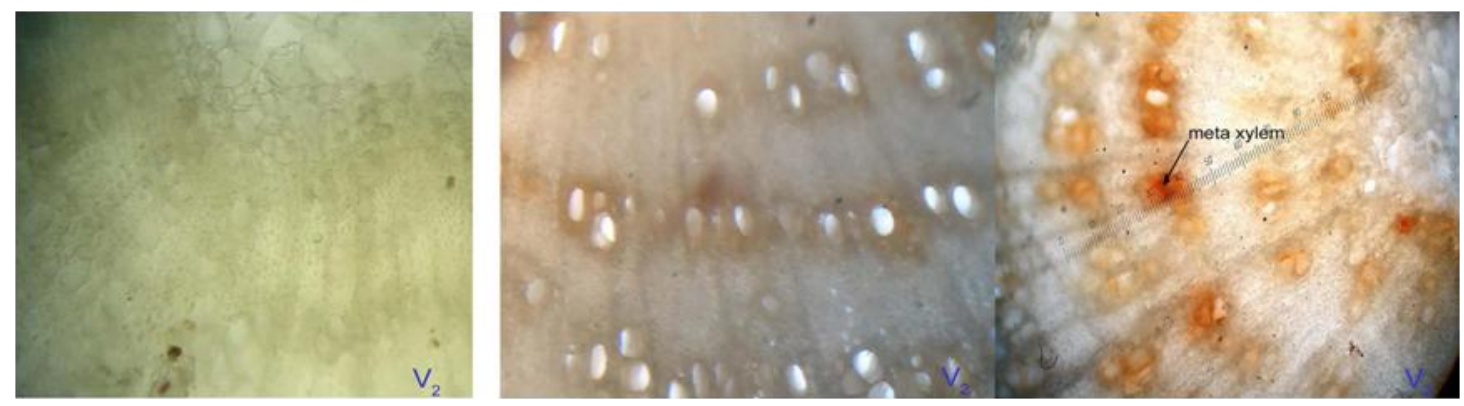

JCP-27 
Figure.5 Histological study of root tissues through microtome section at different stages of infection in sick plot. (This showing tyloses formation and sealing off the xylem vessels with mucilage in the root and stem)

Pre infectional $\left(\mathrm{S}_{1}\right)$
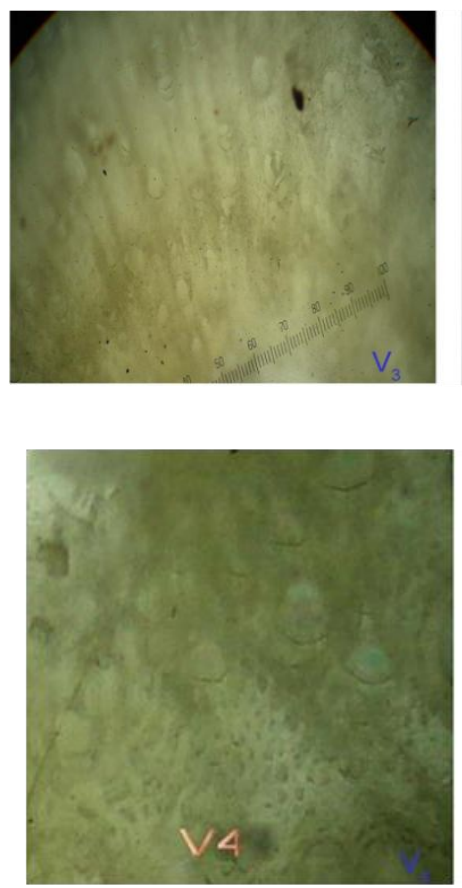

Infectional $\left(\mathrm{S}_{2}\right)$

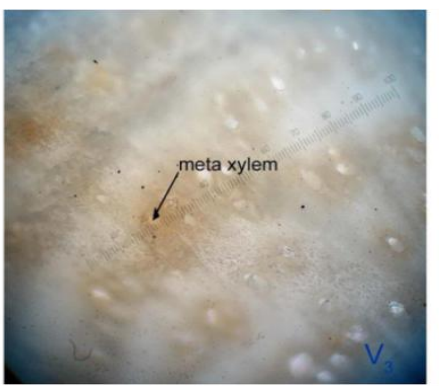

GG-1

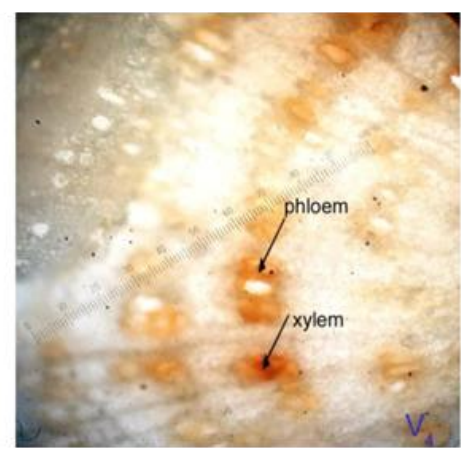

GG-2
Post infectional $\left(\mathrm{S}_{3}\right)$
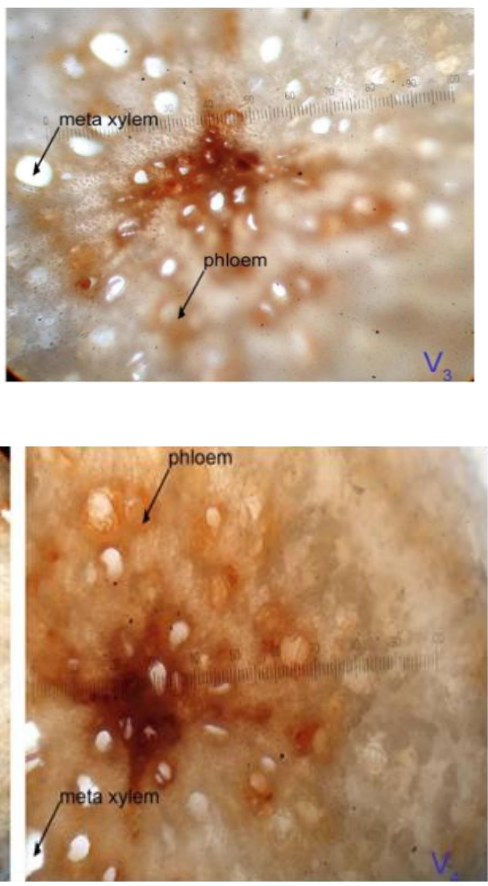

Figure.6 Histological study of root tissues through microtome section at different stages of infection in sick plot. (Cross section of stem from JG-62 inoculated with at Pre, infectional and post infectional stages showing sealing off the vascular system with mucilage)

Pre infectional $\left(\mathrm{S}_{1}\right)$

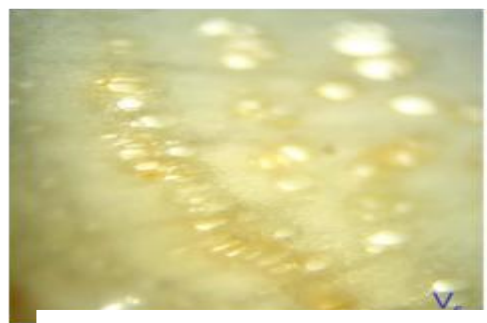

Infectional $\left(\mathrm{S}_{2}\right)$

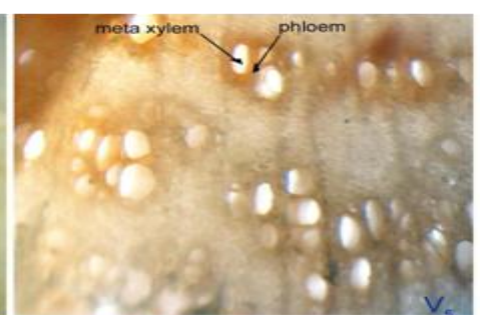

GG-4
Post infectional $\left(\mathrm{S}_{3}\right)$

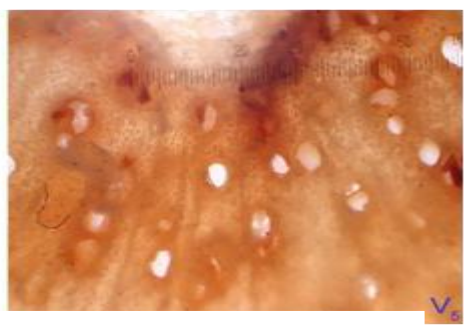

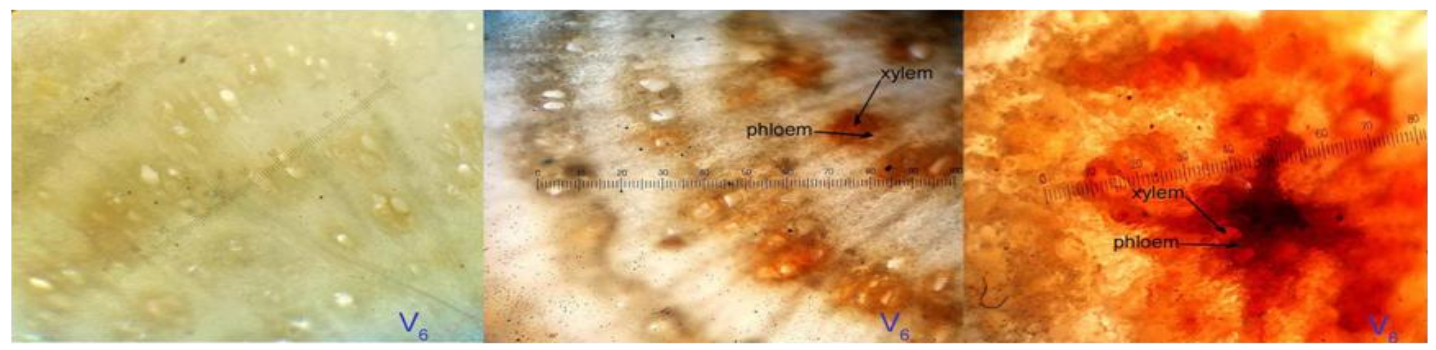

JG-62 
Figure.7 Transverse sections of both healthy and diseased root and stem tissues

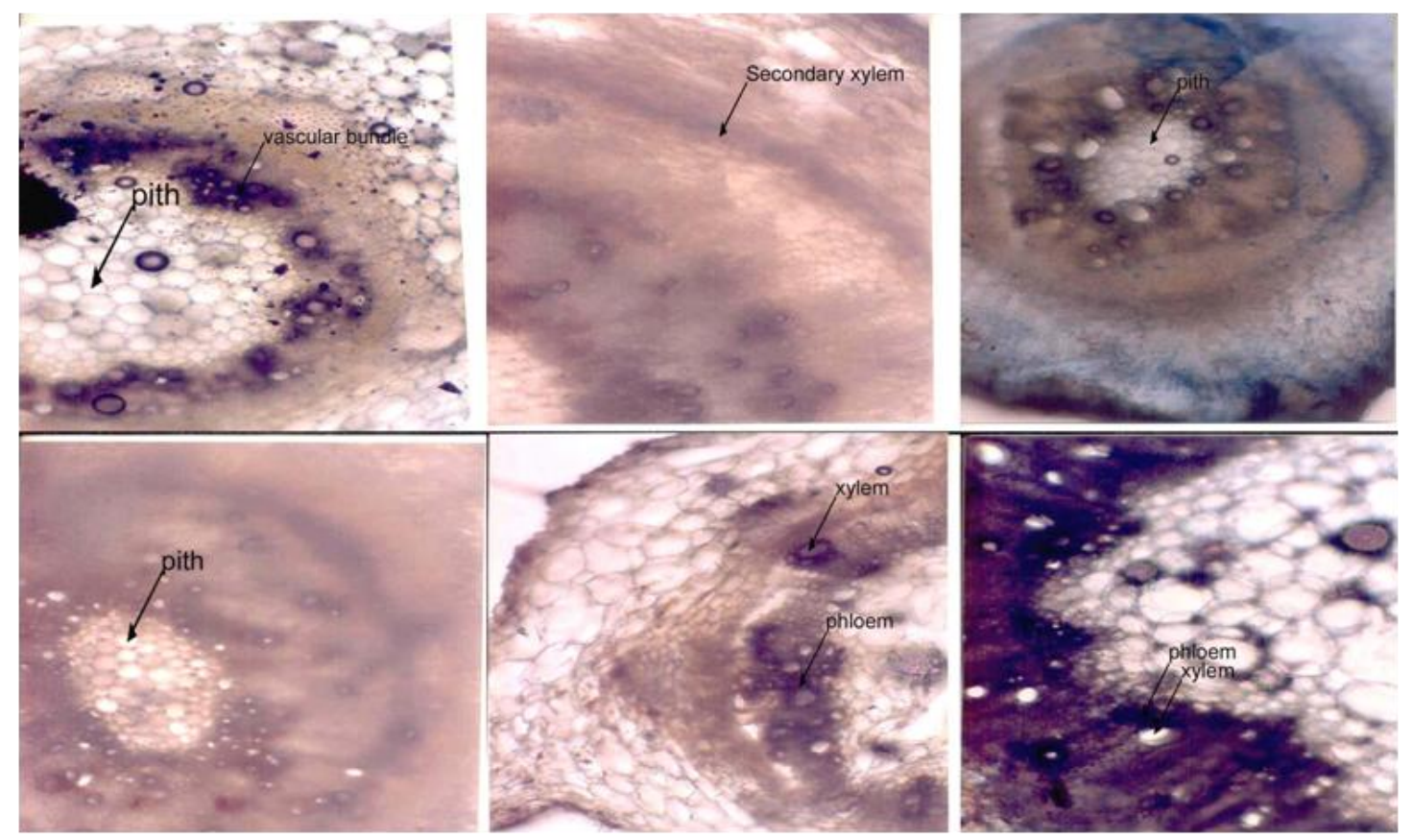

Figure.8 Transverse sections of both healthy and diseased root and stem tissues. ( This showing tyloses formation and sealing off the xylem vessels with mucilage in the root and stem)

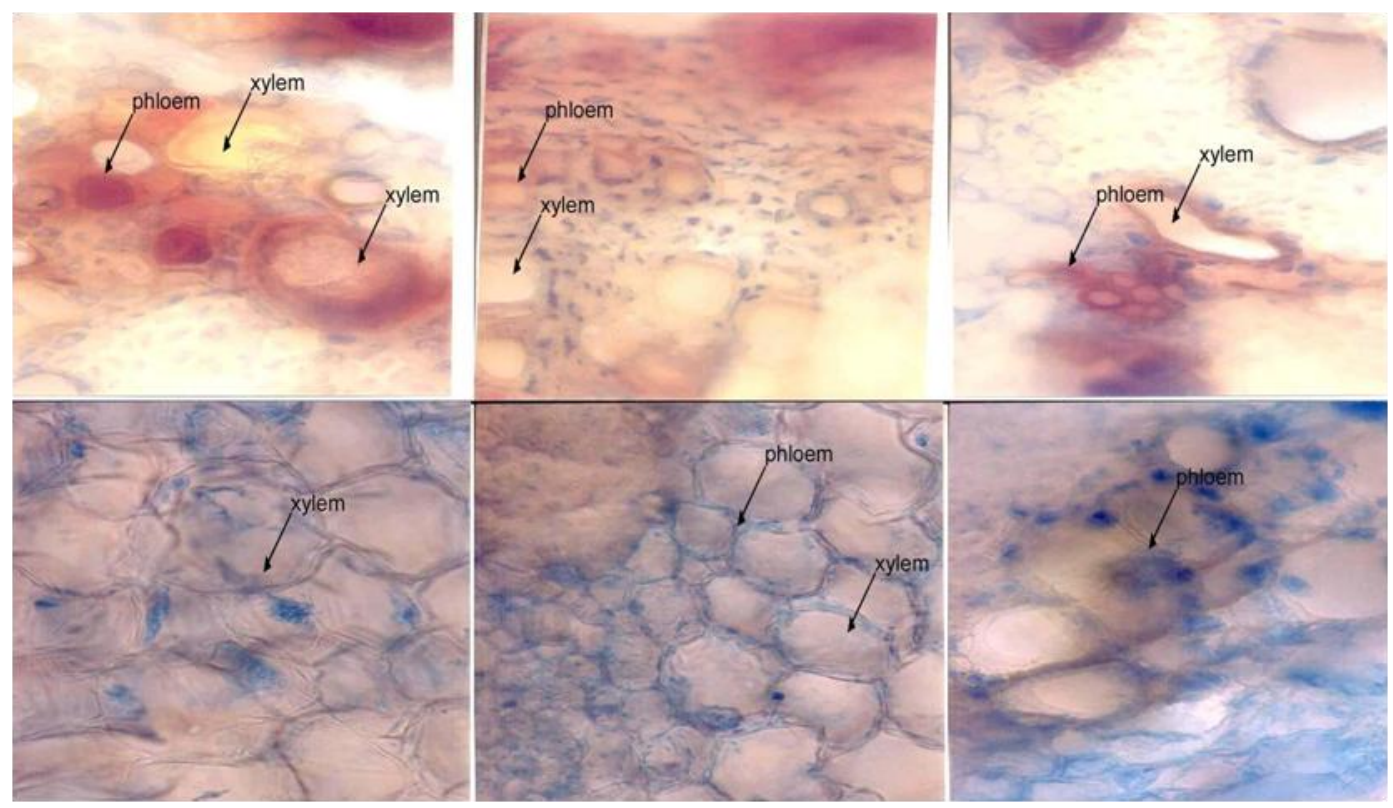


Table.1 Presence (+) or absence (-) of fungal hyphae in tissue of six varieties of chickpea grown in infested plot with Fusarium oxysporium f.sp.ciceri

\begin{tabular}{|c|c|c|c|c|c|c|c|c|c|c|c|c|c|c|c|c|c|c|}
\hline \multirow[t]{2}{*}{ D.A.G } & \multicolumn{3}{|c|}{$\begin{array}{c}\text { V1 } \\
\text { (WR-315) }\end{array}$} & \multicolumn{3}{|c|}{$\begin{array}{c}\mathbf{V}_{2} \\
(J C P-27)\end{array}$} & \multicolumn{3}{|c|}{$\begin{array}{c}V_{3} \\
(G G-1)\end{array}$} & \multicolumn{3}{|c|}{$\begin{array}{c}V_{4} \\
(G G-2)\end{array}$} & \multicolumn{3}{|c|}{$\begin{array}{c}V_{5} \\
(G G-4)\end{array}$} & \multicolumn{3}{|c|}{$\begin{array}{c}\mathbf{V}_{6} \\
(J G-62)\end{array}$} \\
\hline & $\mathbf{R}$ & $\mathbf{S}$ & $\mathbf{L}$ & $\mathbf{R}$ & $\mathbf{S}$ & $\mathbf{L}$ & $\mathbf{R}$ & $\mathbf{S}$ & $\mathbf{L}$ & $\mathbf{R}$ & $\mathbf{S}$ & $\mathbf{L}$ & $\mathbf{R}$ & $\mathbf{S}$ & $\mathbf{L}$ & $\mathbf{R}$ & $\mathbf{S}$ & $\mathbf{L}$ \\
\hline 1 & - & - & - & - & - & - & - & - & - & - & - & - & - & - & - & - & - & - \\
\hline 2 & - & - & - & - & - & - & - & - & - & - & - & - & - & - & - & - & - & - \\
\hline 3 & - & - & - & - & - & - & - & - & - & - & - & - & - & - & - & - & - & - \\
\hline 4 & - & - & - & - & - & - & - & - & - & - & - & - & - & - & - & - & - & - \\
\hline 5 & - & - & - & - & - & - & - & - & - & - & - & - & - & - & - & - & - & - \\
\hline 6 & - & - & - & - & - & - & - & - & - & - & - & - & - & - & - & + & + & - \\
\hline 7 & - & - & - & - & - & - & - & - & - & - & - & - & + & + & - & + & + & - \\
\hline 8 & + & - & - & + & - & - & - & - & - & + & - & - & + & + & - & + & + & - \\
\hline 9 & + & + & - & + & + & - & + & + & - & + & + & - & + & + & - & + & + & - \\
\hline 10 & + & + & - & + & + & - & + & + & - & + & + & - & + & + & - & + & + & - \\
\hline 11 & + & + & - & + & + & - & + & + & - & + & + & - & + & + & - & + & + & - \\
\hline 12 & + & + & - & + & + & - & + & + & - & + & + & - & + & + & - & + & + & - \\
\hline 13 & + & + & - & + & + & - & + & + & - & + & + & - & + & + & - & + & + & - \\
\hline 14 & + & + & - & + & + & - & + & + & - & + & + & - & + & + & - & + & + & - \\
\hline 15 & + & + & - & + & + & - & + & + & - & + & + & - & + & + & - & + & + & - \\
\hline 16 & + & + & - & + & + & - & + & + & - & + & + & - & + & + & - & + & + & - \\
\hline 17 & + & + & - & + & + & - & + & + & - & + & + & - & + & + & - & + & + & - \\
\hline 18 & + & + & - & + & + & - & + & + & - & + & + & - & + & + & - & + & + & - \\
\hline 19 & + & + & - & + & + & - & + & + & - & + & + & - & + & + & - & + & + & - \\
\hline 20 & + & + & - & + & + & - & + & + & - & + & + & - & + & + & - & + & + & - \\
\hline
\end{tabular}

$\mathrm{R}=$ Root; $\mathrm{S}=$ Stem L= Leaf

So at very next two days without the irrigation in between those days $8^{\text {th }}-10^{\text {th }}$ DAG first stage was observed as pre inflectional by visible and histological techniques. Than severity were visible and histologically observed when whole vascular tissue showed browning and yellowish brown fungal infection observed in whole round tissue cross section this stage indicated as inflectional stage as shown in visible symptoms plate $1.1 \mathrm{a}$ to 1.1e. Than after five days it designed as post inflectional stage as shown it plates. Biochemical changes or anatomical changes alteration of the host structure after initial penetration of fungi might have trigger structural changes such as lignin deposition and making cell wall barrier or hardening beyond the reach of action of fungal enzymes. This may be one of the reasons of resistant cultivars to prevent the fungal growth in to resistant host cell. Sinha (2005), ascribed to preformed anatomical root characteristics of plant where fungal progress slow down by characteristics of vascular bundle pattern in resistant line to pigeonpea infected with wilt. Stevenson et al. (1997), Gao et al. (1985) and Pandey et al. (1997) have also found similar result in root tissue of chickpea, tomato and pigeonpea infected by Fusarium oxysporum $\mathrm{f}$ sp. ciceris, Fusarium oxysporum f.sp. Lycopersici and Fusarium udum respectively. The region near hypocotyls was found more venerable to fungal attack at early stage due to thinner epidermal cell walls than in other parts of the root and there is also greater number of pores in this region (Stevenson et al., 1997) Similar results were also found by Sinha (2005) that marked differences in the pattern of vascular bundle in susceptible and resistant cultivar to pigeon pea to wilt disease 
and reported that loss of even one vessels in susceptible would hamper water flow markedly. Movement of pathogen up to stem base of seedling was faster in terms of fungal growth which was higher in susceptible cultivars. Dharmaraj et al. (2005) showed positive correlation among more thickness of root and stem of resistant cultivars to Fusarium udum also histopathological and histochemical study revealed that increase in xylem vessels diameter of root and stem as well as no discoloration in resistant over susceptible cultivar. Cell of pith region were severely distorted in infected stem portion. Where as JG-62 and GG-4, GG-2, GG-1 varieties grown on infested plot at 16DAG showed vascular browning of root tissue and observed occlusion of xylem vessels is due to oxidation of phenolic compound release of enzymes from fungal pathogen and its biochemical interaction with the host cells. Davis et al. (1953). Waggor and diamond (1956), and Pollack and Drysdale (1976) reported that an increase in phenolic compounds and phenol oxidizing enzymes in tomato plants of low resistance compared to plants high resistance to verticillium wilt. Release of fungal toxin also is reported to be one of the factors associated indirectly in the processes of the occlusion of xylem vessels which ultimately resulted in the blocking of water flow through xylem vessels to the upper part of leaf tissue subsequently causing wilting and drooping of plant and death at an advanced stage. In resistant cultivars clear and transparent xylem vessels did not alter the water flow and hence remained free from wilting symptoms. As xylem vessels were not occluded by the fungal growth in resistant varieties it is suggested that though the fungi was able to penetrate from porous hypocotyls region it remained unable to develop further in to the resistant host. In resistant varieties secretion of fungal enzymes and toxin are inhibited by counter attack of host cells. Possibly vascular browning is due to the oxidation of phenolic compounds by release of enzymes from fungal pathogen. Histopathological study indicated that xylem vessel of susceptible cultivars remained completely occluded with fungal hyphae.

It was concluded from the above discussion and study with recorded observation on fungal infected tissues of chickpea seedlings of all six cultivars (root tissue below $2 \mathrm{~cm}$ hypocotyls attachment). clearly indicated that there is no specific timing of infection for plant with pathogen but due to varying nature of resistance mechanism in individual cultivars. It was differ with time, tissues, soil and the cultivar. JG-62 showed infection in stem and root tissues at $6 \mathrm{DAG}$ than at and $7^{\text {th }}$ days after germination GG-4 in root tissues and subsequently presence of fungus observed in all remaining cultivars at starting from 9th days after germination in all six cultivars infected in some portion of stem and whole root surface of remaining cultivars with medium study. So not only the PDA media study is requires for deciding the pre infectional and post infectional stage but also requires microtome section to decides particular stage of infection. Study clearly showed that individual cultivars, host and pathogen interaction and time of infection are differ in all the cultivars.

\section{References}

Baayen, R. P., Sparnaaij, J. L. D., Jansen, J., and Niemann, G. J. (1991). Inheritance of resistance in carnation against Fusarium oxysporum f.sp. dianthi races 1 and 2 , in relation to resistance components. Netherlands Journal of Plant Pathology, 97, 73-86.

Chaube, H.S. and Pundhir, V.S. (2005). Crop diseases and their managementEdition-2005. Prentice Hall of India Pvt. Ltd. NewDelhi. Chapter-22 Vascular wilt. Pp 461 
Davis, D., Waggoner, P.E and Diamond, A.E. (1953). Conjugated phenol in Fusarium wilt syndrome. Nature. 172:959

Dharmaraj, P.S.; Gopal Rathod, Lokesh, R.; Naik, M.K and Nalin Prabhakaran. (2005).characterization of wilt resistance and susceptible genotypes of pigeonpea (Cajanus cajan (L) on morphological histological basis. A525. Abstract.IFLRC-IV.Octomber 2005., New Delhi india. Pp 310.

Gao, H.; Beckman, C.H and Mudlea, W.C. (1985). The rate of colonization as a measure of genotypic interaction between various cultivars of tomato and various formae or races of Fusarium oxysporum. f.sp .ciceris. Physiol.Mol.plant pathol. 45:29-43.

Halila, M.H. and Strange, R.N. (1996). Identification of the causal agent of wilt of chickpea in Tunisia as Fusarium oxysporum f.sp. ciceri race 0 . Phytopathol. Mediterr. 35:67-74.

Jimenez-Fernandez, D., Landa, B. B., Kang, S., Jimenez-Diaz, R. M., and NavasCortes, J. A. (2013). Quantitative and microscopic assessment of compatible and incompatible interactions between chickpea cultivars and Fusarium oxysporum f.sp. ciceris races. PloS One, 8(4), e61360.

Nene, Y.L.; Haware, M.P.; Reddy, N.M.V.; Philps, J.P.; Castro E.L.; Kotasthane, S.R.; Gupta, O.; Singh, G.; Shukia, P and Sah, R.P. (1989). Identification of broad based and stable resistance to wilt and root-rots in chickpea. Indian
Phytopathol., 42:499-505

Pandey, R.N.; Power, S.E and Bhatia, C.R. (1997). Effect of culture filtrate of Fusarium udad and fusaric acid on wilt susceptible and resistant cultivars. Indian Phytopathology. 48:444-448.

Pouralibaba, H.R., Pérez-de-Luque, A. \& Rubiales, D. (2017) Histopathology of the infection on resistant and susceptible lentil accessions by two contrasting pathotypes of Fusarium oxysporum f.sp. lentis . Eur J Plant Pathol 148, 53-63 (2017). https://doi.org/10.1007/s10658-0161068-6.

Pollack, C.J and Drysdale, R.B. (1976). The role of phenolic compounds in the resistance of tomato cultivars to Verticillium albo-atrum. Phytopathology Z.86:56.

Sinha, P (2005). Pigeonpea wilt resistance basis and pathogenic variability-A-523. Abstract.IFLRC-IV.Octomber 2005., New Delhi india. Pp 309.

Stevenson, P.C., Turner, B.C. and Haware, M.P. (1997). Phytoalexin accumulation in the roots of chickpea (Cicer arietinum L.) seedlings associated with resistance to Fusarium wilt (Fusarium oxysporum f.sp. ciceris). Physiological and Molecular Plant Pathology. 50: 167178.

Waggoner, P.E and Diamond, A.E. (1956). Polyphenol oxidase and substrates in potato stem. Phytopathology., 46:495497.

\section{How to cite this article:}

Rathod, P. J., D. N. Vakharia and Vala, A. G. 2020. Histo-Pathological Study in Chickpea (Cicer arietinum. L) Plant Parts Infected with Fusarium oxysporum f.sp ciceri. Int.J.Curr.Microbiol.App.Sci. 9(06): 1894-1905. doi: https://doi.org/10.20546/ijcmas.2020.906.235 